$12-31-2020$

\title{
Forming a collective Brand: Women's community small medium enterprises and intellectual property rights
}

Tuti Widiastuti

Bakrie University, Indonesia, tuti.widiastuti@bakrie.ac.id

Nurul Asiah

Bakrie University, Indonesia, nurul.asiah@bakrie.ac.id

See next page for additional authors

Follow this and additional works at: https://scholarhub.ui.ac.id/ajce

Part of the Women's Studies Commons

\section{Recommended Citation}

Widiastuti, Tuti; Asiah, Nurul; and David, Wahyudi (2020). Forming a collective Brand: Women's community small medium enterprises and intellectual property rights. ASEAN Journal of Community Engagement, 4(2), 452-467.

Available at: https://doi.org/10.7454/ajce.v4i2.1059

Creative Commons License

(c) (i) ()

This work is licensed under a Creative Commons Attribution-Share Alike 4.0 License.

This Case-Based Article is brought to you for free and open access by the Universitas Indonesia at ASEAN Journal of Community Engagement. It has been accepted for inclusion in ASEAN Journal of Community Engagement. 


\title{
Forming a collective Brand: Women's community small medium enterprises and intellectual property rights
}

\author{
Tuti Widiastutia ${ }^{*}$, Nurul Asiaha, Wahyudi Davida \\ a Bakrie University, Indonesia
}

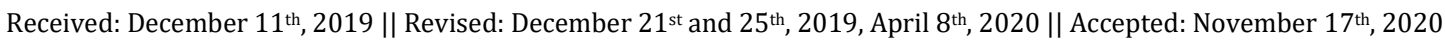

\begin{abstract}
Women, as part of a community, have a limited role in developing themselves and getting various opportunities in the professional domain. Some women move to a community to conduct productive activities, such as the Kota Pelangi Community in the Pancoran subdistrict of South Jakarta. They consist of homemakers who are still productive and have started various small, processed food businesses. However, their efforts are constrained by the quality of processed food products and they have not been able to compete with the market. Branding or updating a brand can be a long process, but it requires considerable input and creativity. Brands that go through the collective branding process too quickly risk being unprofessional and not being taken seriously. This community service program assists with licensing and branding the community's product. The first aspect is improving product quality through innovation and the use of technology. Next is branding development and increased sales packaging through ecommerce marketing assistance, which includes displaying products in various bazaars and exhibitions. It is also necessary to conduct business financial management and bookkeeping training. Last is the provision of aid for licensing and capital management. The program was conducted to encourage and increase entrepreneurial women's productivity in the Pancoran subdistrict to develop skills, including soft skills, to be economically and socially independent.
\end{abstract}

Keywords: collective brand; intellectual property rights; women; small medium enterprise; Kota Pelangi Community.

\section{Introduction}

Small and medium enterprises (SMEs) have a vast potential for the growth and innovation in products (World Intellectual Property Right, 2006). However, awareness of SME entrepreneurs regarding the importance of using intellectual property rights to support their business activities is still low. The Indonesian Ministry of Law and Human Rights stated that the number of SMEs that possess trademark applications is still relatively low. Out of 64.1 million SMEs in Indonesia, only 10,632 have registered trademarks (Djumena, 2020). Using brands as product markers, SME entrepreneurs can help consumers recognize their products, making it easier for consumers to find and buy these products. Indonesia has various local specialties from diverse regions, which are

\footnotetext{
*Correspondence Author: tuti.widiastuti@bakrie.ac.id
} 
Tuti Widiastuti, Nurul Asiah, Wahyudi David | ASEAN Journal of Community Engagement | Volume 4, Number 2, 2020

homemade products made by local women as gifts for their neighbors (Hubeis et al., 2015; Sari et al., 2018).

These SME craft people, or entrepreneurs can take advantage of trademark rights to market their unique food products. Here, the variety and variation in the value of the expression of the food produced by women SME entrepreneurs can be identified by trademarks. The use of trademark rights to identify food products can also increase the competitiveness of local SME entrepreneurs against the backdrop of global food products (Iswanaji, 2016; Satiyawan, 2008; Sihombing, 2018; Sukmadewi, 2017).

According to the Intellectual Property Handbook of the World Intellectual Property Organization (WIPO) (2006), brands are interpreted as “... any sign that individualizes the goods of a given enterprise and distinguishes them from the goods of its competitors." In this definition, it is stated that the brand must have a distinguishing power, or it must be distinctive and may not have the potential to deceive, or it should not be deceptive.

The Agreement on Trade-Related Aspects of Intellectual Property Rights (1994) states that a trademark is any sign or combination of marks capable of distinguishing goods or services from one another. The sign includes words, including individual names, letters, numbers, figurative elements, and color combinations, as well as sign combinations. According to the Trademark Law in Indonesia Number 15 of 2001, a brand is a sign in the form of images, names, words, letters, numbers, an arrangement of colors, or a combination of these elements that have distinguishing features and are used in trade or service activities. Here, the brand can be divided into two types: the handle brand used on traded goods and the service marks used in traded services.

According to Indonesia Regulation No. 19 article 1 no. 4 of 1992 (DPR RI, 1992), collective brands are brands used on goods or services with the same characteristics traded by several legal entities to distinguish them from other similar goods or services. The regulations in the Trademark Law in Indonesia No. 15 of 2001 (Sugiyarti, 2016) for the use of collective brands must contain: (a) the nature, general characteristics or quality of goods or services to be produced and traded; (b) arrangements for owners of collective brands to effectively monitor the use of the brand; and (c) sanctions for violating the collective brands' regulations.

The use of the brand as an identity and marker of local products is considered a solution that helps consumers differentiate local food products from imported food 
products and helps the craftsperson's distinguish the food products with their respective products' characteristics and distinctiveness. Accordingly, this study examines the effectiveness of women entrepreneurs' brand awareness to mark their respective food products. The study also considers the importance of women using brands in trade competition.

Globally, SMEs in developing countries are trying to survive and expand their activities in other markets, which is not easy. Hassan and Mohamed (2015) found that the obstacles faced by SMEs in their efforts to survive make it a model worth studying. SMEs contribute significantly to economic and social growth, and the sector is considered a business field endowed with the potential for innovation, job creation, and income growth. In terms of producer protection, this study examines the effectiveness of brand law objectives to create fair business competition; the desire of women SME entrepreneurs to register brand rights; the form of brand rights enforcement activities by the authorities; and the form and role of the local government in ensuring that SME holders of brand rights can exercise their rights effectively.

The rolling reforms allowed the broader involvement of women in development. In the current reform era, which has been a little more open, women can claim gender equality and justice space. Gender Watch is a strategy to advocate for policy based on pro-women data (Hasanah, 2017). Efforts to increase women's involvement in development to produce economic welfare are essential and a priority for the female community, as public policy has a different impact on men and women. Further, public policy can also eliminate gender discrimination and injustice in the long term. Therefore, by incorporating a feminist perspective as a primary consideration in developing and implementing female empowerment, we can hope that gender equality and justice can be realized.

Indiworo (2016) states that women have the potential to undertake various productive activities that produce and can help the family economy and, more broadly, the national economy. Moreover, this potential is across fields and sectors. In addition to having the potential and competence to develop small businesses, these women are also businesspeople, managers or supervisors, or workers (Zahroh, 2017). The quality and professionalism continue to improve by increasing their abilities and skill (Ahmad, 2012; Alshgawi, 2015; Gupta \& Mirchandani, 2018; Haugh, 2007; Holgersson, 2013; 
Huggins \& Weir, 2012; Ng \& Kee, 2012; Omri, Ayadi-Frikha, \& Bouraoui, 2015; Thoma \& Bizer, 2013).

Women's empowerment holds the potential for economic activity. Women in everyday life still have a limited role in self-development and obtaining various employment opportunities. Women of productive age without a permanent job should create potential employment. Some of them move to communities for more productive activities, like the community in the Kelurahan Pancoran Jakarta Selatan (Pancoran Sub District of South Jakarta). They consist of homemakers who are still young enough to be productive and have started various small businesses in processed food. However, their business is constrained by several factors.

This research attempts to build collective brand management to increase awareness of the importance of intellectual property rights for women food entrepreneurs in the Kota Pelangi Community. This awareness is an integral part of making the products more valuable and recognized in the community. The research was also done to strengthen the position of micro, small, and medium enterprises. The primary function of brand management is for consumers to characterize a company's product (be it goods or services) to distinguish it from other similar products of the company or the company's competitors (Haugh, 2007).

A common obstacle faced by small entrepreneurs is maintaining product quality and looking for the right marketing place (Santoso, Anita, \& Mayanti, 2018). In addition, communities have limited access to capital: do not understand business financial management; products are not standardized; there are no trademarks; and low production capacity (Wediawati \& Setiawati, 2015). A simple calculation can be used to implement extension activities and business development training for processed food products (Damayanti, Suandi, \& Kernalis, 2015). The empowerment program aims to encourage and increase the women's community entrepreneurship's productivity in the Pancoran subdistrict, ensuring that they have both hard and soft skills to be economically and socially independent. Community empowerment can also be done by providing management, business, and technical assistance (Octavia, Masriani, \& Rosita, 2015). The empowerment program is expected to shape entrepreneurial quality improvements, including increasing community capacity, participation, economic activity, and technology-based capabilities that focus on market access. 
Kota Pelangi is expected to become a role model for women, specifically in the Pancoran region and throughout Indonesia; it is widely associated with entrepreneurship independence. It is necessary to have training initiatives and mentor support to improve and develop existing business activities to achieve these expectations. However, this research has begun by creating a website displaying the Kota Pelangi women's entrepreneurs' brands. Communication aims to attract a broad audience (Lukito \& Arvanda, 2018). Based on this background, the main issues that will be discussed in this research are:

1. What form of collective brand management do the women food product entrepreneurs in the Kota Pelangi Community use?

2. How is the intellectual property rights awareness in women food entrepreneurs in Kota Pelangi Community used to take advantage of trademark protection?

3. What are the strategies and empirical efforts to increase trademark awareness by women entrepreneurs in food products in the Kota Pelangi Community?

\section{Methods}

This research uses the descriptive qualitative method, where data is collected through in-depth interviews before and after the training is conducted. Data is collected before implementing the training focused on finding information about women SMEs' problems and obstacles, especially in creating collective brand management. Data collection after training primarily seeks information on how to raise awareness of women entrepreneurs to manage the collective brand; their efforts in fostering intellectual property rights awareness; and how the strategies and empirical forms increase trademark awareness in women small business enterprises.

The leader and members of the Kota Pelangi Community are vital informants in this study. The research triangulation makes use of marketing communication experts and food technology experts. The interview method was used to obtain data from the informants to answer the research problem. All the collected data was processed and analyzed using interpretive techniques.

The data analysis is used to find solutions to the problems of women's business groups. The analysis helps create the collective brand's management, encourage intellectual property rights awareness, and develop strategies and empirical forms of 
efforts to increase trademark awareness by women entrepreneurs in food products in the Kota Pelangi Community.

\section{Results and Discussion}

\subsection{Brand collective management in food products of Kota Pelangi community}

The difficulty at the initial formation of the collective brand was determining a brand name for various products. Previously, every member of the Kota Pelangi Community had a name for their product. After several discussions at the members' meeting, the name Komunitas Kota Pelangi was chosen as a joint trademark name. Family branding gives the same brand to several products within that brand for easy identification by the public. Examples of family branding are the Honda car brands, including the Honda Brio, Honda Mobilio, Honda CRV, etc.

In the case of Pelangi City Community, a family brand name was used for the entire product line. By building customer trust and loyalty through a family brand name, the entire product line will benefit. However, the use of a family brand name can also bring problems if one of the products has a bad reputation in the market; it can damage the reputation of all product lines and its parent brand. Therefore, they need mutual awareness to maintain a collective brand.

The SME players in the Kota Pelangi Community understand the philosophy and meaning of their brands. The Pelangi City Community implements a strategy where they feature superior products juxtaposed with the name of the product or store, they have so that consumers can immediately know how the product meets their needs and wants. For Kota Pelangi Community partners to feel proud of their brand, they can support other members to advance their business ventures, introducing an element of coaching to community partner members.

For partners without a brand or who are yet not confident of the brand they have, the Kota Pelangi Community administrators implement a strategy that uses the product name. A brand includes its name or direct business owner, the party that conducts the production and marketing distribution. Its use is intended to instill confidence in new community members.

The collective brand classification consists of trademarks and service brands. The collective brand's differences lie in the brand user, which may be a collective, whereas individuals usually use the trademark or service. Collective brands may be used by 
several people or a combination of people and legal entities or joint corporations. According to the WIPO IP Handbook, collective brands are usually owned by an association or company, whose members can use the collective brands for marketing their products. Usually, the association establishes criteria for entrepreneurs who want to use the collective brand, such as quality standards, which allows individual entrepreneurs to strive toward.

A brand can be a sign, picture, symbol, name, word letters, numbers, color arrangement, or a combination of these elements that distinguish a product from competing products through the uniqueness of the product. It can provide added value for customers, establishing a close relationship between consumers and companies by giving a psychological meaning.

The selection of products based on the brand can be made because of product marketing's success, the reputation possessed by the producer or goodwill, the guarantee of the product's quality, or the consideration that the product meets consumer tastes. Sometimes, the product's selection can be linked to a certain image by the consumer to the brand of a particular product (Sardjono, Prasatyo, \& Larasati, 2013). The image is related to the reputation of the product or manufacturer. Consumers may be loyal and continue to buy or use that brand's products because of their reputation or image (Hakenes \& Peitz, 2009). However, a collective brand is a brand that is used for goods and services with the same characteristics traded by several persons or legal entities jointly to distinguish between goods or other similar services.

Brand sharing can be an option in the mechanism of information dissemination, as in the case of the brand umbrella (Hakenes \& Peitz, 2008). Castriota and Delmastro (2010) look at the influence of individual factors, collective reputation, and institutional regulation on the reputation of each wine company in Italy (Costanigro, McCluskey, \& Goemans, (2010); McQuade, Salant, \& Winfree, 2012). This option is used when consumers are interested in the products offered. In this instance, the characteristic product information is based on seeing the other products sold under the same umbrella brand, but with different information. 


\subsection{Intellectual Property Rights Awareness in Kota Pelangi Community}

The Kota Pelangi Community shows that women entrepreneurs have processed collective brands' registration, as the food products they sell or produce have unique Jakarta's regional characteristics. However, some argue that protection is needed for entrepreneurs of shared brands with the same local features. Some consider that protection is not necessary because every entrepreneur produces products with different characteristics. Regarding the Kota Pelangi Community, the informant did not know about the program, its purpose, function, and procedure. Some respondents who had heard did not have the same understanding of the brand's purpose and function. Some argue that collective brands are a form of standardization appropriate for product community standards. The Kota Pelangi Community product brand shows that the food product is a quality product.

Intellectual Property Rights (IPR) are the rights that arise from the results of thought to produce a product or process that is useful for humans. In essence, IPR is the right to enjoy the results of intellectual creativity economically. The view that the IPR objects arise out of human intellectual endeavors in order to women entrepreneurs place more importance on their brands than competitors' brands. These rights (IPR) are divided into two parts: copyright and industrial property rights. Industrial property rights include patent, industrial design, trademark, tackling fraudulent competition (repression of unfair competition), layout design of integrated circuits, and trade secret.

In Article 7 of Trade-Related Aspects of Intellectual Property Rights (1994), the objectives of the protection and enforcement of IPRs are to encourage innovation and the transfer and dissemination of technology. They also obtain mutual benefits between the producers and users of technological knowledge, create social and economic welfare, and balance rights and obligations. These objectives are because most of the orders they produce come from individual buyers (Trade Related Aspects of Intellectual Property Rights, 1994).

The basis for considering the making of the Trademark Law is to realize that fair business competition and the provision of good services to the public are related to brand protection through the registration of IPR. Here, the rationale is related to the context of the objectives of the Trademark Law to: 
1. Make the entrepreneur not want to imitate or falsify the brand.

2. Make the entrepreneur voluntarily register her trademark to the Directorate General of IPR.

3. Make entrepreneurs work together in advancing their business by utilizing Collective Brand protection.

The findings also showed that although most of the entrepreneurs wanted to register their brand, their desire was hampered by not knowing the procedures for registering brands, waiting for their brands to be well-known, and not prioritizing support businesses. The average informant knows that ownership of the registered brand's rights can strengthen their position to sue those who imitate their brand or products.

It is essential to protect brands as they are used to differentiate one product from another. Initially, SME entrepreneurs were more concerned with selling first than protecting their IPR as they lacked the awareness of SMEs' intellectual property rights. In the end, SMEs' business products are often sold without a brand and their products are resold using third party trademarks and services. This practice is detrimental to SME entrepreneurs as they do not get value-added from the products and services they sell and buy. An additional effort needs to be made to empower SMEs to understand the importance of trademarks and IPR registration. After that, SMEs need to be encouraged to immediately take care of IPR by utilizing digital services to obtain their trademarks more easily.

\subsection{Strategies and empirical forms in Kota Pelangi community}

Factors that can influence the speed of adoption of IPR programs include the attributes of innovation, communication channels, communicators, and SMEs' characteristics (Nur et al., 2016). The attributes of innovation can influence decisionmaking by considering the relative benefits, suitability, and complexity. In contrast, the communication channel includes mass and interpersonal media channels. The speed of innovation adoption is related to one's decision-making process in a social system. The innovation programs are not easy because the program presented is new, so people have much to consider.

The ability to build a successful brand reputation depends on the group's size, based on the trust that is divided into larger groups (Huck \& Lunser, 2009) and group types 
(Escalas \& Bettman, 2005). The Kota Pelangi Community consists of 30 small women entrepreneurs, with an average of middle school and high school education, producing food and clothing. The level of education is not considered in determining adoption decisions but having more experience influences decisions (Nur et al., 2016). Kampmeier and Simon (2001) reinforce the notion that group identification increases when people are oriented between groups. This strategy can increase the perceived distance between the group itself and other relevant groups, thus filling the need for differentiation at the intergroup level and meeting the demand for inclusion at the intragroup level.

Partners want to adopt trademark patent registration programs because they are not charged for registering trademark IPRs. The partners know that the registration fees for trademark IPRs are expensive and the process is complicated. Therefore, this program provides facilitation, and the partners benefit by registering the trademark. Huggins and Weir (2012) said that the inability to create value from intellectual assets, especially those relating to new product development, restricts the development of effective innovation processes, with innovation more likely to be undertaken through less formal and systematic channels.

Some strategies can be put forward for why a name must be connected to a collective brand, including:

a. Products can compete in new market segments when there is a possibility of failure, which could be detrimental to the collective brand.

b. The individual brand market segments may not be suitable for the family brand segment. A family brand is aimed at the public, who know the brand name well. In other words, the brand is solid as a market leader, so there is no need to change the brand. For this reason, it is necessary to perform various promotional activities to introduce the collective brand name on a massive and continuous basis.

c. Brand combinations are a name that contains a family brand and an individual brand. The intent and purpose are to support the product's image by highlighting the parent brand's name. Here, the collective brand name must be prioritized over the individual brand. Over time, the collective brand must be able to become a strong family brand. 


\section{Conclusion}

SME products have the advantage of local products that have important sources and compositions that need to be protected by their trademarks. So, SMEs must understand that trademark registration can strengthen the protection of IPR for their products and businesses. By building an emotional response and creating positive reactions from community members, SME players can build a collective trademark. There were no

problems concerning the use of collective brands in the community of women entrepreneurs. There are a few cases of brand disputes among women SME entrepreneurs. The varied desire of women SMEs entrepreneurs to use and register collective brands, on average, the informants considered that the food products they produced had Jakarta regional characteristics.

The brand is an asset for a business. A SMEs entrepreneur wants to develop their business into a business model then having a brand is a must. The selling value is influenced by the brand value generated by the branding efforts of the owner, in addition to other things such as system investment. SMEs products already have their own brand, and then what needs to be done is to continue to improve product quality, maintain a good brand image. Through branding, the brand of your products and services will be easily recognized by consumers. This will help increase sales of the SMEs business products and services.

Brand is an important asset for business so that special protection is needed for the brand owned. In fact, a brand is a package that refers to the same term. Meanwhile, branding is more about building a brand, one of which can be seen from the level of public awareness of the product or service brand. A trademark owner registers intellectual rights, the trademark will be legally protected. Therefore protecting business marks by registering them early is a precautionary step in business. The state protects the economic rights of each holder of the trademark rights. This economic right can be realized in the form of IPR.

\section{Acknowledgments}

The implementation of the community service was funded by the DRPM Ristekdikti through the KOPERTIS Region III Jakarta grant with reference to the Letter of Assignment Agreement of the Implementation of the Public Service Program Budget Year 2019 assignment number 035/KM/PNT/2018. 


\section{Author Contribution}

Tuti Widiastuti, Nurul Asiah, and Wahyudi David conceived of the presented idea. Tuti Widiastuti developed the theory and Wahyudi David performed the data analysis. Tuti Widiastuti verified the analytical methods. Tuti Widiastuti encouraged Nurul Asiah to investigate dynamics of collective brand formation in Kota Pelangi Community and supervised the findings of this work. All authors discussed the results and contributed to the final manuscript.

\section{References}

Ahmad, S. Z. (2012). Micro, Small and Medium-Sized Enterprises Development in the Kingdom of Saudi Arabia: Problems and Constrains. World Journal of Entrepreneurship, Management and Sustainable Development, 8, 217-232. https://doi.org/10.1108/20425961211276606

Alshgawi, M. (2015). Assessing Women Entrepreneurship in Arab Saudi: Strategies for Success. Ajman Journal of Studies and Research, 14, 155-185.

Castriota, S., \& Delmastro, M. (2010). Individual and Collective Reputation: Lessons from the Wine Market (in Italian). L'Industria, 31(1), 149-172.

http://dx.doi.org/10.2139/ssrn.1349992

Costanigro, M., McCluskey, J., \& Goemans, C. (2010). The Economics of Nested Names: Name Specificity, Reputations, and Price Premia. American Journal of Agricultural Economics, 92(5), 1339-1350. Stable URL:

https://www.jstor.org/stable/40931090

Damayanti, Y., Suandi, \& Kernalis, E. (2015). Pelatihan dan Penyuluhan pembuatan Telur Itik Asin dalam Upaya Pengembangan Kewirausahaan Baru di Desa Tanjung Harapan Cupak Kecamatan Danau Kerinci Kabupaten Kerinci. Jurnal Pengabdian pada Masyarakat, 30(4), 36-42.

http://portalgaruda.fti.unissula.ac.id/index.php?ref=browse\&mod=viewarticle\& article $=420180$

Djumena, E. (2020). Dari 64,1 Juta UMKM, Baru 10.632 yang Mengurus Merek Dagang. https://money.kompas.com/read/2020/07/17/161100826/dari-64-1-jutaumkm-baru-10.632-yang-mengurus-merek-dagang.

DPR RI. (1992). Undang-undang republik Indonesia Nomor 19 Tahun 1992 Tentang Merek. http://www.dpr.go.id/dokjdih/document/uu/635.pdf 
Escalas, J. E., \& Bettman, J. R. (2005). Self-Construal, References Groups, and Brand Meaning. Journal of Consumer Research, 32, 378-389. https://doi.org/10.1086/497549

Gupta, N., \& Mirchandani, A. (2018). Investigating Entrepreneurial Success Factors of Women-Owned SMEs in UAE. Management Decision, 56.

https://doi.org/10.1108/MD-04-2017-0411

Hakenes, H., \& Peitz, M. (2008). Umbrella Branding and the Provision of Quality. International Journal of Industrial Organization, 26(2), 546-556.

https://doi.org/10.1016/j.ijindorg.2007.03.004

Hakenes, H., \& Peitz, M. (2009). Umbrella Branding and External Certification. European Economic Review, 53(2), 186-196.

https://doi.org/10.1016/j.euroecorev.2008.03.006

Hasanah, I. (2017). Mendorong Kebijakan Publik Profeminisme melalui Gerakan Gender Watch: Studi di Kabupaten Gresik. Jurnal Perempuan, 22(1), 35-42. http://indonesianfeministjournal.org/index.php/IFJ/article/viewFile/157/159

Hassan, B., \& Mohamed, B. (2015). Role of SMEs in the Economic and Social Development: Case of Terroir Products in Souss Massa Draa Region (Marocco). Advances in Economics and Business, 3(8), 340-347.

http://www.academia.edu/download/42530343/Book_of_Proceedings_esd_NY

C_2014_Published1.pdf\#page=706

Haugh, H. (2007). Community-led Social Venture Creation. Entrepreneurship: Theory \& Practice, 31(2), 161-182. https://doi.org/10.1111/j.1540-6520.2007.00168.x

Holgersson, M. (2013). Patent Management in Entrepreneurial SMEs: A Literature Review and An Empirical Study of Innovation Appropriation, Patent Propensity, and Motives. R\&D Management, 43(1), 21-36. https://doi.org/10.1111/j.14679310.2012.00700.x

Hubeis, M., Purwanto, B., Dewi, F. R., Widyastuti, H., \& Febtyanisa, M. (2015). Strategi Pengembangan UMKM Pangan yang Berdaya Saing di Indonesia. Prosiding Seminar Hasil-hasil PPM IPB, I, 126-143.

http://lppm.ipb.ac.id/wp-content/uploads/2017/04/B504.pdf 
Tuti Widiastuti, Nurul Asiah, Wahyudi David | ASEAN Journal of Community Engagement | Volume 4, Number 2, 2020

Huck, S., \& Lunser, G. K. (2009). Group Reputations: An Experimental Foray. Journal of Economic Behavior and Organization, 73(2), 153-157.

https://doi.org/10.1016/j.jebo.2009.09.001

Huggins, R., \& Weir, M. (2012). Intellectual Assets and Small Knowledge-Intensive Business Service Firms. Journal of Small Business Enterprise Development, 19(1), 92-113. https://doi.org/10.1108/14626001211196424

Indiworo, H. E. (2016). Peran Perempuan dalam meningkatkan Kinerja UMKM. Jurnal Equilibria Pendidikan, 1(1), 40-58. https://doi.org/10.26877/ep.v1i1.1806

Iswanaji, C. (2016). Faktor-faktor Penentu Penguatan Ekonomi terhadap Keunggulan Daya Saing Produk Batik di Kelurahan Kramar Selatan dengan Pendekatan One Village One Product. Prosiding Seminar Nasional Strategi pengembangan UMKM dan Industri Kreatif Sebagai Mesin Pertumbuhan Ekonomi Indonesia, (pp. 461475).

Jensen, K. (2015). Do's and Dont's of B@B Branding. https://www.bopdesign.com/bopblog/2015/03/dos-dontks-of-b2b-branding/

Kampmeier, C., \& Simon, B. (2001). Individuality and Group Formation: The Role of Independence and Differentiation. Journal of Personality and Social Psychology, 448-462. https://doi.org/10.1037/0022-3514.81.3.448

Lukito, Y. N., \& Arvanda, E. (2018). Diffusing signage as visual communication in the implementation of Pico Hydro Technology in Batu Roto, Bengkulu Province, Indonesia. ASEAN Journal of Community Engagement, 2(1), 87-96.

https://doi.org/10.7454/ajce.v2i1.108

McQuade, T., Salant, S., \& Winfree, J. (2012). Regulating an Experience Good Produced in the Formal Sector of a Developing Country when Consumers cannot Identify Producers. Review of Development Economics, 16(4), 512-526.

https://doi.org/10.1111/rode.12001

Ng, H. S., \& Kee, D. H. (2012). The Issues and Development of Critical Success Factors for the SMEs in a Developing Country. International Business Management, 6, 680691.

https://www.researchgate.net/profile/Hee_Song_Ng/publication/269648071_T he_Issues_and_Development_of_Critical_Success_Factors_for_the_SME_Success_in _a_Developing_Country/links/5856377608aeff086bfa0dad.pdf 
Nur, F., Sarwoprasodjo, S., \& Hubeis, M. (2016). Kecepatan Adopsi Program Fasilitasi Hak Kekayaan Intelektual Merek Dagang untuk Usaha Kecil Menengah. Jurnal Manajemen IKM, 11(2), 183-190. https://doi.org/10.29244/mikm.11.2.183-190

Octavia, A., Masriani, I., \& Rosita, S. (2015). Pemberdayaan Masyarakat melalui Optimalisasi Program Bank Sampah dengan Bantuan Teknis dan Manajemen Usaha pada KSM Limbah dan Maidanul Ula Kota Jambi. Jurnal Pengabdian pada Masyarakat, 30(3), 40-49.

https://studylibid.com/doc/1939942/pemberdayaan-masyarakat-melaluioptimalisasi

Omri, A., Ayadi-Frikha, M., \& Bouraoui, M. A. (2015). An Empirical Investigation of Factors Affecting Small Business Success. Journal of Management Development, 34, 1073-1093. https://doi.org/10.1108/JMD-07-2013-0088

Santoso, H., Anita, M., \& Mayanti, D. (2018). Community Economic Empowerment through Cultivation of Enceng Gondok Program Using Community Engagement Program Approach in West Aceh Regency Post Conflict and Natural Disaster Earthquake and Tsunami 2004. Jurnal Pengabdian Kepada Masyarakat, 3(2), 161-168. https://doi.org/10.22146/jpkm.28974

Sardjono, A., Prasatyo, B. A., \& Larasati, D. G. (2013). Pelaksanaan Perlindungan Hukum Merek untuk pengusaha UKM Batik di Pekalongan, Solo, dan Yogyakarta. Jurnal Hukum dan Pembangunan, 44(4), 496-517.

http://dx.doi.org/10.21143/jhp.vol43.no4.1497

Sari, D. A., Hakiim, A., Efelina, V., Asiah, N., \& Sukanta. (2018, September). PKM Kelompok Usaha Dodol kabupaten Bekasi Jawa Barat. Jurnal Abdimas, 5(1), 1-5. https://doi.org/10.31227/osf.io/hgzb9

Satiyawan, D. (2008). Pelaksanaan Undang-undang Merek pada UKM (Usaha Kecil Menengah) Kecamatan Ceper Kabupaten Klaten dalam rangka perlindungan Hukum dari Tindakan Pemalsuan Merek. Surakarta: Universitas Muhammadiyah Surakarta.

Sihombing, E. N. (2018, December). Kebijakan Afirmatif Bagi Usaha Mikro, Kecil dan Menengah di Bidang Kekayaan Intelektual. Jurnal Rechts Vinding, Media Pembinaan Hukum Nasional, 7(3), 427-444.

http://dx.doi.org/10.33331/rechtsvinding.v7i3.273 
Tuti Widiastuti, Nurul Asiah, Wahyudi David | ASEAN Journal of Community Engagement | Volume 4, Number 2, 2020

Sugiyarti, Y. (2016). Perlindungan Merek Bagi Pemegang Hak Merek Ditinjau dari Undang-undang Nomor 15 Tahun 2001 Tentang Merek. Jendela Hukum, 3(1), 3241. https://doi.org/10.24929/fh.v3i1.354

Sukmadewi, Y. D. (2017). Sosialisasi Legalitas dan manajemen Usaha Bagi Pelaku Usaka UMKM di Kecamatan pendurung Kota Semarang [Laporan Pengabdian kepada Masyarakat]. Universitas Semarang.

https://repository.usm.ac.id/files/dedication/B267/20171114030327-

Sosialisasi-Legalitas-dan-Manajemen-Usaha-bagi-Pelaku-Usaha-UMKM-diKecamatan-Pedurungan-Kota-Semarang.pdf

Thoma, J., \& Bizer, K. (2013). To Protect or Not to Protect? Modes of Appropriability in the Small Enterprise Sector. Research Policy, 42, 35-49.

https://doi.org/10.1016/j.respol.2012.04.019

Trade-Related Aspects of Intellectual Property Rights (TRIPS). (1994). Agreement on Trade-Related Aspects of Intellectual Property Rights.

https://www.wto.org/english/docs_e/legal_e/27-trips.pdf

Wediawati, B., \& Setiawati, R. (2015). IBM Kelompok Usaha Bersama Perempuan Kepala Keluarga (KUBE-PEKKA) di Kecamatan Telanaipura Kota Jambi. Jurnal Pengabdian pada Masyarakat, 30(1), 10-17.

http://portalgaruda.fti.unissula.ac.id/index.php?ref=browse\&mod=viewarticle\& article $=357223$

World Intellectual Property Organization (WIPO). (2006). Membuat Sebuah Merek, Pengantar Merek untuk Usaha Kecil dan Menengah.

https://www.wipo.int/export/sites/www/sme/en/documents/guides/translati on/making_a_mark_indo.pdf

Zahroh, T. R. (2017). Peran UMKM Konveksi Hijab dalam meningkatkan Kesejahteraan Ekonomi Perempuan, Studi Kasus Konveksi Hijab di Desa Pasir Kecamatan Mijen Kabupaten Demak [Undegraduate thesis, UIN Walisongo]. Walisongo Institutional Repository. http://eprints.walisongo.ac.id/7987/ 